\title{
A study on the use of public transportation during the COVID-19 pandemic
}

\author{
Titi Kurniati $^{1 *}$ and Junico Nobel Valentino ${ }^{1}$ \\ ${ }^{1}$ Civil Engineering Department, Engineering Faculty, Andalas University, Indonesia
}

\begin{abstract}
During the COVID-19 pandemic, public transportation occupancy has decreased significantly. In addition to the sluggish economy, the COVID-19 health protocol rules require that only 50 percent of passengers can be transported for public transportation. This study tries to identify the use of public transportation and the factors that influence this use during the adaptation period for the new habits of the COVID-19 pandemic. Data on the frequency of using public transportation before and during the pandemic was processed with the index formula. Before the pandemic period, using public transportation was often, with an index value of $60.8 \%$. During the pandemic period, $10.1 \%$ of respondents did not do activities outside the home. Respondents who moved outside their homes $(89.9 \%)$ used private vehicles $(88.3 \%)$ and $11.7 \%$ public transportation for their trips. The type of public transportation often used is online transportation (motorbike and car) by $62.1 \%$. The frequency of use of public transportation is rare (44.9\%) and very rarely (40.8\%); the rest are often $(9.7 \%)$ and very often $(4.5 \%)$. This value will produce an index value of $44.5 \%$ with a sparse interval interpretation. A hypothesis test was conducted between the respondent's characteristics (gender, age, occupation, and vehicle ownership) and the frequency of using public transportation. The result shows that the factor influencing the frequency of using public transportation is the respondent's occupation.
\end{abstract}

\section{Introduction}

In early 2020, a new virus, namely a new type of coronavirus (SARS-CoV-2) and its disease called Coronavirus disease 2019 (COVID-19), took the world by storm because of its widespread and speedy spread. Through the Director-General Dr. Tedros Adhanom Ghebreyesus, the World Health Organization or WHO declared the Corona COVID-19 virus a global pandemic on March 12, 2020. With the determination of the pandemic, Dr. Tedros asked each country to: activate and improve emergency response mechanisms, communicate to citizens about the risk of the coronavirus, and urge them to protect themselves, as well as find, isolate, test, and treat COVID-19 patients and trace any contact they have come into contact with [1].

Following up on this, the Indonesian government also stated that the Coronavirus problem had become a nonnatural national disaster. The Central Government and Regional Governments and their staff work hand in hand to make several tactical steps to prevent the spread of the Corona COVID-19 Virus in the community. The steps taken by the government in certain areas are Large-Scale Social Restrictions (PSBB) and, after that, the implementation of new habits (new normal).

The policy, which was followed up by massive socialization to the community to work from home, a study from home, and worship from home, and the closure of tourist sites had limited the movement of people outside their homes.

Transportation is one area that is restricted in the activities of Large-Scale Social Restrictions (PSBB) and during the new normal period. Restrictions placed on public transportation are related to the number of passengers and operating hours. For traffic users who depend on public transportation, this policy results in limited access to public transportation.

MarkPlus, Inc. explains the results of a quick survey participated by 100 respondents throughout Indonesia, the majority of whom actively use public transportation. From the survey results, $66 \%$ of respondents use public motorcycles such as online motorcycle taxis, 50\% minibusses, $46 \%$ city buses, $44 \%$ city trains, $31 \%$ taxis, and $1 \%$ bajaj. The survey results show a high enough fear for people to use public transportation during the COVID19 period. $40 \%$ of respondents stated that they had never used public transportation since the pandemic, and 30\% of respondents limited the intensity of their use [2].

According to the Jabodetabek Transportation Management Agency (BPTJ), public transportation in the DKI Jakarta area decreased significantly during the COVID-19 pandemic. TransJakarta services during April 2020 (until 15/4/2020) decreased by around 83,000 people per day. In fact, under normal conditions, the number of passengers reaches around 840,000 people per day. Meanwhile, on the Mass Rapid Transit (MRT)

\footnotetext{
*Corresponding author: titi@eng.unand.ac.id
} 
service, there was a 47 percent decrease in passengers during March 2020. Usually, the daily MRT passengers reach around 85,000 people, but this has decreased to around 45,000 people [3].

Not only in Indonesia, but the impact of the COVID19 pandemic on a significant decrease in the use of public transportation has also occurred in cities around the world such as London, New York City, Berlin, Paris, and Sydney. In Paris, for example, the decline was about $80 \%$ compared to before the pandemic [4]. In India, the pandemic has caused $19 \%$ of Indian bus operators to lose $90 \%$ of their passengers and the remaining $91 \%$ without passengers at all [5].

The purpose of this study is to identify the factors influencing the use of public transportation, as well as to analyze the factors that have the greatest influence on the use of public transportation during the adaptation of new habits to the COVID-19 pandemic.

\section{Literature Review}

Several studies related to the use of transportation during the pandemic in Indonesia have been published. The choice of mode during the COVID-29 pandemic in Tegal city is influenced by variables of socio-economic characteristics. To analyze, used PLS Structural Equation Modelling (SEM) method. The result of the analysis is that the mode choice is influenced by the vehicle ownership variable with a coefficient $=0.81$. In contrast, the variables of distance, self-preservation behavior during the pandemic, and the purpose of the trip do not significantly affect people's choice of transportation mode during the pandemic [6].

The research [7] results concluded that there were changes in activity and travel due to the COVID-19 pandemic; mainly, the average travel frequency to work or school decreased by $66 \%$. Multiple linear regression analysis was used to investigate travel-activity changes. The linear regression model between changes in travel activity and mental health variables, and sociodemographic variables met the evaluation of the feasibility of the model. However, the value of the coefficient of determination or $\mathrm{R}$ is relatively low. So it is necessary to consider other independent variables.

The results of the study on the factors that influence the decision to use the Bekasi Commuter Line KRL services during the COVID-19 pandemic with factor analysis are the equipment completeness variable on the health protocol factor with a contribution of $83 \%$, the frequency of the number of departures on the availability factor with a contribution of $84 \%$, the availability of payment methods on the convenience factor with a contribution of $86 \%$, the new policy of PT. KCI on the convenience factor with $83 \%$ contribution, affordable cost on the cost factor with a contribution of $90 \%$, the development and feasibility of technology on the safety factor with a contribution of $81 \%$, and a sense of security from crime at the station on the security factor with a contribution of $86 \%$ [8].

\section{Methodology}

\subsection{Data Collection}

Data collection was carried out through online questionnaire interviews. Questionnaire questions are designed into three (3) parts. The characteristic of the questions for the three parts of the questionnaire is closed questions. Questionnaires are created in google docs forms.

The first part is a question regarding the socioeconomic characteristics of the respondents (gender, age, occupation, vehicle ownership). Part 2 contains questions regarding the movement of respondents before the pandemic. The period before the COVID-19 pandemic is before March 18, 2020. The questions are the vehicle used for movement, the type, and method of driving using a private vehicle, the purpose of the movement, the type of public transportation that is often used, and the frequency of using public transportation. Section 3 asks about the respondent's movement during the pandemic (after March 18, 2020). The questions include activities out of the house during the pandemic, the type of vehicle used, the type of public transportation that is often used, the purpose of movement, and the frequency of using public transportation.

The data collection was carried out for 1 month in September 2020. At that time, a new habit adaptation period was applied. The government's policy on public transportation is the limitation of public transport passengers with the occupation rate of $50 \%$ of capacity. Dissemination of questionnaires through social media researchers.

\subsection{Data Processing}

The analytical method to explain the movement of transportation users before and during the COVID-19 pandemic is a descriptive statistical method. The statistical hypotheses test at a significant level, $\alpha=5 \%$, was carried out to compare the frequency of using public transportation before and during the COVID-19 pandemic. A chi-square test is carried out to determine the factors that affect the use of public transportation during the COVID-19 pandemic. Hypothesis and chi-square test using statistical SPSS 22 software.

For the question of frequency of use of public transportation, the answers are designed on a Likert scale with four scale choices, namely:

Score 1 . Very rarely

Score 2. Rarely

Score 3. Often

Score 4. Very often

The conclusion regarding the frequency of the respondent's trip is the result of the value generated by using the Index $\%$ formula.

Index $\%=$ Total Score $/ \mathrm{Y}$ x 100

$\mathrm{I}=100 /$ total Likert score

$\mathrm{Y}=$ highest Likert score $\mathrm{x}$ number of respondents 
$\mathrm{I}=$ score interval

Criteria for interpretation of scores based on intervals:

Value $0 \%-24.99 \%=$ very rarely

Value $25 \%-49.99 \%$ = rarely

Value $50 \%-74.99 \%=$ often

Value $75 \%-100 \%=$ very often

\section{Results}

The survey results collected 267 responses. The personal characteristics of respondents, as shown in Table 1 , the respondent is dominated by the age of $17 \leq$ age $<25$ years with occupation as a student. Only $20 \%$ of respondents do not own a motorized vehicle.

Table 1. Personal characteristics of the respondent

\begin{tabular}{|c|c|c|}
\hline \multicolumn{2}{|c|}{ Characteristics } & $\begin{array}{c}\text { Percentage } \\
(\%)\end{array}$ \\
\hline \multirow{2}{*}{ Gender } & Male & 34.5 \\
& Female & 65.5 \\
\hline \multirow{4}{*}{ Age } & Age $<17$ & 23.6 \\
& $17 \leq$ age $<25$ & 68.5 \\
& $25 \leq$ age $<33$ & 7.1 \\
& $33 \leq$ age $<41$ & 0 \\
& Age $\geq 41$ & 0.7 \\
\hline \multirow{5}{*}{ Occupation } & Student & 83.1 \\
& employees & 12.4 \\
& Businessman & 1.9 \\
& others & 2.6 \\
\hline \multirow{2}{*}{ Vehicle } & Not Owning & 20.6 \\
ownership & Motorcycle (MC) & 70.0 \\
& Car & 5.2 \\
& MC and car & 4.1 \\
\hline
\end{tabular}

Table 2. The distribution of respondent's domiciles

\begin{tabular}{|l|c|}
\hline \multicolumn{1}{|c|}{ Province } & Percentage (\%) \\
\hline Sumatera Barat & 52.0 \\
\hline Kepulauan Riau & 29.6 \\
\hline Riau & 7.5 \\
\hline Banten & 3.0 \\
\hline Jawa Barat & 2.25 \\
\hline Jambi & 1.5 \\
\hline Sumatera Utara & 1.5 \\
\hline DKI Jakarta & 0.75 \\
\hline DI Yogyakarta & 0.37 \\
\hline Bengkulu & 0.37 \\
\hline Lampung & 0.37 \\
\hline Sumatera Selatan & 0.37 \\
\hline Jawa Timur & 0.37 \\
\hline
\end{tabular}

The distribution of respondents' domiciles can be seen in Table 2, where most of them are domiciled in Sumatera Barat Province.

The survey results show that before the COVID-19 pandemic, $21.3 \%$ of respondents used public transportation to travel to school or campus. The more widely used public transportation is online taxis (car and motorcycles, MC). A total of $22.1 \%$ of respondents use public transportation every day (very often) (Table 3).

Table 3. Activity before the COVID-19 pandemic

\begin{tabular}{|c|c|c|}
\hline \multicolumn{2}{|c|}{ Activity } & $\begin{array}{c}\text { Percentage } \\
(\%)\end{array}$ \\
\hline \multirow{2}{*}{$\begin{array}{l}\text { the vehicle used } \\
\text { for movement }\end{array}$} & Private vehicle & 78.8 \\
\hline & Public transportation & 21.3 \\
\hline \multirow{6}{*}{$\begin{array}{l}\text { The type and } \\
\text { method of } \\
\text { driving using a } \\
\text { private vehicle }\end{array}$} & MC (ride alone) & 67.0 \\
\hline & MC ( delivered and & 17.5 \\
\hline & picked up ) & \\
\hline & car (drive alone) & 7.5 \\
\hline & car (delivered + picked up) & 2.3 \\
\hline & car and motorbike & 5.7 \\
\hline \multirow{4}{*}{$\begin{array}{l}\text { The purpose of } \\
\text { the movement }\end{array}$} & school/campus & 62.9 \\
\hline & market/mall & 44.6 \\
\hline & workplace & 16.1 \\
\hline & others & 7.9 \\
\hline \multirow{4}{*}{$\begin{array}{c}\text { The type of } \\
\text { public } \\
\text { transportation } \\
\text { that is often } \\
\text { used }\end{array}$} & & 28.5 \\
\hline & paratransit & 16.5 \\
\hline & bus & 55.1 \\
\hline & $\mathrm{MC} /$ car online & \\
\hline \multirow{4}{*}{$\begin{array}{l}\text { The frequency } \\
\text { of using public } \\
\text { transportation. }\end{array}$} & very rarely & 9.0 \\
\hline & rare & 60.7 \\
\hline & often & 8.2 \\
\hline & very often & 22.1 \\
\hline
\end{tabular}

During the pandemic, $10.1 \%$ of respondents did not do activities outside the home. Most respondents (89.9\%) who move out of the house use private vehicles $(79.4 \%)$ and public transportation $10.1 \%$ (Table 4).

The data processing results on the frequency of using public transportation before the COVID-19 pandemic obtained an index of $60.86 \%$, and during the COVID-19 pandemic, it was $44.48 \%$. Interpretation of the interval score of the $60.86 \%$ index value was often $(50 \%$ $74.99 \%$ ) and $44.48 \%$ was rare $(25 \%-49.99 \%)$ (Tabel 5). There was a $16.4 \%$ reduction in the use of public transportation.

The null hypotheses assumption $\left(\mathrm{H}_{0}\right)$ in the hypotheses test is that there is no difference between the frequency of using public transportation before and during the COVID-19 pandemic at a significant level of $\alpha=5 \%$. The result is $\mathrm{P}=0.001<0.05$; then the decision is to reject $\mathrm{H}_{0}$. It was concluded that there was a significant 
difference between the use of public transportation before and during the COVID-19 pandemic.

Table 4. Activity during the COVID-19 pandemic

\begin{tabular}{|c|c|c|}
\hline \multicolumn{2}{|c|}{ Activity } & $\begin{array}{c}\text { Percentage } \\
\text { (\%) }\end{array}$ \\
\hline $\begin{array}{c}\text { Activities out of } \\
\text { the house }\end{array}$ & Yes & 89.9 \\
\hline The type of vehicle & Private vehicle & 10.1 \\
\hline used & Public & 88.3 \\
The type of public & paratransit & 11.7 \\
transportation that & bus & 19.5 \\
is often used & Online MC/car & 18.4 \\
& taxis & 62.1 \\
\hline \multirow{2}{*}{$\begin{array}{c}\text { The purpose of the } \\
\text { movement }\end{array}$} & market/mall & 32.4 \\
& workplace & 10.3 \\
& others & 3.2 \\
\hline The frequency of & very rarely & 40.8 \\
using public & rare & 44.9 \\
transportation. & often & 9.7 \\
& very often & 4.5 \\
\hline & & \\
\hline
\end{tabular}

Table 5. The frequency of using public transportation

\begin{tabular}{|c|c|c|}
\hline $\begin{array}{c}\text { The frequency of using } \\
\text { public transportation }\end{array}$ & Before & During \\
\hline Mean & 2.43 & 1.78 \\
\hline Standar deviation & 0.933 & 0.799 \\
\hline Index\% & 60.86 & 44.48 \\
\hline Interpretation & often & rare \\
\hline
\end{tabular}

A chi-square statistical test was carried out to determine whether or not there is a relationship between socio-economic characteristics and the frequency of public transportation during the COVID-19 pandemic. Previously, it was necessary to make a crosstab analysis table between socio-economic characteristics (gender, age, occupation, and ownership of motorized vehicles) and the frequency of use. Table 6 shows a crosstab analysis between gender and frequency and table 7 between occupation and frequency.

From the results of statistical tests obtained P-value (Asymp. Sig.) $=0.537>0.05$. Conclusion Null Hypotheses (H0) are not rejected, meaning that there is no significant relationship at a significant level of $\alpha=5 \%$ between gender and the frequency of using public transportation during the COVID-19 pandemic.

Table 6. Crosstab analysis gender vs frequency

\begin{tabular}{|c|c|c|}
\hline \multirow{2}{*}{ Frequency } & \multicolumn{2}{|c|}{ Gender } \\
\cline { 2 - 3 } & Male & Female \\
\hline Very rarely & 40 & 69 \\
\hline Rarely & 40 & 80 \\
\hline Often & 10 & 16 \\
\hline Very often & 2 & 10 \\
\hline
\end{tabular}

Table 7. A chi-square statistical test

\begin{tabular}{|c|c|c|c|}
\hline & Value & df & $\begin{array}{c}\text { Asymp. } \\
\text { Sig. (2- } \\
\text { sided) }\end{array}$ \\
\hline Pearson Chi-Square & 2.176 & 3 & 0.537 \\
\hline Likelihood Ratio & 2.386 & 3 & 0.496 \\
\hline $\begin{array}{c}\text { Linear by Linear } \\
\text { Association }\end{array}$ & 0.835 & 1 & 0.361 \\
\hline N of Valid Cases & 267 & & \\
\hline
\end{tabular}

Table 8. Crosstab analysis occupation vs frequency

\begin{tabular}{|c|c|c|c|c|}
\hline \multirow{2}{*}{ Occupation } & \multicolumn{4}{|c|}{ Frequency } \\
\cline { 2 - 5 } & $\begin{array}{c}\text { Very } \\
\text { rarely }\end{array}$ & Rarely & Often & $\begin{array}{c}\text { Very } \\
\text { often }\end{array}$ \\
\hline Student & 95 & 100 & 19 & 8 \\
\hline Employees & 7 & 17 & 6 & 3 \\
\hline Businessman & 1 & 2 & 1 & 1 \\
\hline Others & 6 & 1 & 0 & 0 \\
\hline
\end{tabular}

From the results of statistical tests obtained P-value (Asymp. Sig.) $=0.035<0.05$. Conclusion Null Hypotheses $\left(\mathrm{H}_{0}\right)$ are rejected, meaning that there is a significant relationship at a significant level of $\alpha=5 \%$ between occupation and the frequency of using public transportation during the COVID-19 pandemic.

Table 9. Summary of Chi-Square test results

\begin{tabular}{|c|c|c|}
\hline Variable & P-value & Conclusion \\
\hline Gender & 0.537 & $\mathrm{H}_{0}$ not rejected \\
\hline Age & 0.546 & $\mathrm{H}_{0}$ not rejected \\
\hline Occupation & 0.035 & $\mathrm{H}_{0}$ rejected \\
\hline $\begin{array}{c}\text { Vehicle } \\
\text { ownership }\end{array}$ & 0.664 & $\mathrm{H}_{0}$ not rejected \\
\hline
\end{tabular}


The results of the chi-square statistical test of socioeconomic variables with frequency are summarized in table 9. Of the four relationships tested, only the occupation variable has a relationship with the frequency of use of public transportation during the COVID-19 pandemic at a significant level of $\alpha=5 \%$.

\section{Results}

Before the pandemic period, using public transportation was often, with an index value of $60.8 \%$. During the pandemic period, $10.1 \%$ of respondents did not do activities outside the home. Respondents who moved outside their homes $(89.9 \%)$ used private vehicles $(88.3 \%)$ and $11.7 \%$ public transportation for their trips. The type of public transportation often used is online transportation (motorbike and car) by $62.1 \%$. The frequency of use of public transportation is rare $(44.9 \%)$ and very rarely $(40.8 \%)$; the rest are often $(9.7 \%)$ and very often $(4.5 \%) . \%)$. This value will produce an index value of $44.5 \%$ with a rare interval interpretation. There was a $16.4 \%$ reduction in the use of public transportation.

Based on the hypothesis test at a significant level of $\alpha=5 \%$, it can be concluded that there are differences in the frequency of using public transportation before and during the COVID-19 pandemic.

The results of the chi-square statistical test of socioeconomic variables with frequency concluded that only employment variables had a relationship with the frequency of use of public transportation during the COVID-19 pandemic at a significant level of $\alpha=5 \%$

The authors would like to thank Engineering Faculty for the financial support provided through Hibah Publikasi Fakultas Teknik Tahun Anggaran 2021.

\section{References}

1. G. L. Widyaningrum, "WHO has declared COVID19 a global pandemic. What does it mean? National Geographic Indonesia, 12 March 2020, https://nationalgeographic.grid.id/read/132059249/w ho-tetapkan-COVID-19-sebagai-pandemi-globalapa-maksudnya [accessed Oct. 16, 2020]

2. S. Mayasari, "Survey: Public transportation users have dropped dramatically since the COVID-19 pandemic" (in English) , kontan.go.id, 19 June 2020, https:/industri.kontan.co.id/news/survei-penggunatransportasi-umum-turun-drastis-sejak-pandemiCOVID-19 (accessed Oct. 16, 2020)

3. R. Kurniawan, "Users of Jabodetabek Public Transportation Decreased Drastically During WFH", https://otomotif.kompas.com/read/2020/04/20/1545 00315/pengguna-angkutan-umum-jabodetabekmenurun-drastis-selama-wfh. (accessed Oct. 16, 2020)

4. Moovit, "Moovit Public Transit Index," May 2020 https://moovitapp.com/insights/en/Moovit_Insights Public_Transit_Index-countries. (accessed Feb. 1ㅎ, 2021)

5. UITP, "Bus operations in India: what has been the impact of COVID-19?," UITP, May 27, 2020. https://www.uitp.org/news/bus-operations-indiawhat-has-been-impact-COVID-19 (accessed Feb. 16, 2021)

6. P. Rusmandani, R. S. Setiawan and N. Fitriani, Civil Engineering Journal / 15 No.2 119-126 (2021)

7. M. Rizki, D. Prasetyanto and A. Maulana, Environmentally Friendly Technology Journal, 5 No.2. 125-135 (2021)

8. A. M. Monica, Sukanta and Winarno Industrial Engineering Journal. 5 No.2. 17-22 (2021) 